\title{
Short Paper \\ E-Participation: Community Involvement Level Related to Different Services of Local Government Unit Dfficials
}

\author{
Francis F. Balahadia \\ Graduate Studies, University of the East \\ Laguna State Polytechnic University \\ francis.balahadia@1spu.edu.ph \\ Wellanie M. Molino \\ Graduate Studies, University of the East \\ wellanie_molino@tup.edu.ph \\ Joel M. Bawica \\ Graduate Studies, University of the East \\ Laguna State Polytechnic University \\ joel.bawica@1spu.edu.ph \\ Irish C. Juanatas \\ Graduate Studies, University of the East \\ icjuanatas@feutech.edu.ph \\ Henry Dyke Balmeo \\ Graduate Studies, University of the East \\ Melvin A. Ballera \\ Graduate Studies, University of the East
}

Date received: May 19, 2017

Date received in revised form: July 14, 2017; August 30, 2017

Date accepted: August 31, 2017

Recommended citation:

Balahadia, F. F., Molino, W. M., Bawica, J. M., Juanatas, I. C., Balmeo, H. D., \& Ballera, M. A. (2017). Eparticipation: Community involvement level related to different services of local government unit officials. International Journal of Computing Sciences Research, 1(2), 10-20. doi: 10.25147/ijcsr.2017.001.1.07

\begin{abstract}
Purpose - This paper seeks to answer the level and extent of involvement of the community in the government services to explore how information technologies may work to improve the services to the citizens as an input to egovernance initiative.

Method -The researchers conducted a series of activities for data gathering, such as interview, focus group discussion and survey. Questionnaires were used to collect data to support the rationality of the study. The study used the descriptive statistics from the gathered data to determine the needs of the community. Specifically, mean scores and standard deviation were computed from the results of different statements per category based on the survey questions. Regression analysis method was used to identify the factors affecting the involvement of the respondents related to the services from the LGU. ANOVA was also used to identify the differences among respondents' levels of involvement such as the age group, civil status, and educational attainment.
\end{abstract}


Results - The findings provided justifications to identify factors affecting the involvement of the respondents in LGU services. It also indicated that they have the same level of involvement in terms of sex, civil status, and educational attainment. However, there is a positive association between community involvement and community respondent age group in terms of involvement level.

Conclusion - The study showed that there is lack of information dissemination about different services, programs, activities and projects in the community that cause low community involvement. Accessibility to technology of the respondents, dissemination of information to respondents through the web, level of public web applicability of the respondents, and level of assessment on incident report in the community of the respondents are the factors affecting the involvement of the respondents in the different services of local government officials which lead as a basis for creating the e-participation website for local government unit.

Recommendations - The use of ICT (information and communication technology) in the Local Government must be applied in a bigger community or group in a barangay; on the other hand, local municipalities must implement the proposed system or e-participation portal to identify the benefits from the delivery of services of the officials.

Research Implications - The development of the government services such as e-participation initiatives inevitably need to take into consideration the inclusion of proper information dissemination, crafting of new models of policy formulation, and the formulation of alternative approaches for connecting people to the political process though the ICT. Motivations for community involvement are also important. Future efforts could stress on the community their involvement in changing the local conditions they are not pleased with. Uses of this finding in program/policy development could take a variety of forms.

Keywords - barangay, citizen, community, digital divide, e-participation, involvement, local government, services, proper authorities

\section{INTRODUCTION}

Community participation is an important aspect for the proliferation of information using Information and Communication Technology (ICT). It can also be used to support innovation within the paradigm of knowledgedriven economy. E-participation as an application of ICT, involves the extension and transformation of participation in societal democratic, information provision, service delivery and decision-making process. The ICT can also be used in the barangay level. The barangay level is considered as a critical partner of the national government in local development undertakings in the country. Section 384 of the local Government Code of the Philippines states that the barangay, as the basic political unit, serves as the primary planning and implementing unit of government policies, plans, programs, projects, and activities in the community, as a forum wherein the collective views of the people may be expressed, crystallized and considered, and where disputes may be amicably settled. This is because of the strategic situation being at the grassroots level where effective and efficient services are delivered to a community.

In local governance, citizen participation means people's evaluation of their own needs and levels of participation in project planning and budget monitoring (McCaffrey, 2003). Active participation is an important process in improving public resource management to reduce unwanted behaviors by making public servants and political leaders liable to the people. Moreover, McCaffrey (2003), Haase and Pratschke (2003), Lenhart (2003), and Sciadas (2002) stated that lack of participation occurs as a result of the digital divide specifically in the barangay level. Problems within the community are not always communicated to the barangay chairman or councilors. The involvement of the local citizens in any decision-making body in a barangay holds great significance for stakeholders. It is likewise a challenge for researchers to acquire efficient data that will support developing an eparticipation application.

Many strands of existing studies may contribute to a better understanding of e-participation and development of future research directions. This study is part of the research presented by Balahadia, Fabito and Fernando (2015) which is entitled E-Participation: Incident Mapping Portal for Local Government Units (LGU). The said study aimed to develop a technology-driven tool which improves community engagement in public services and monitoring to help reduce corruption and improve services to the community. From the previous study, this paper 
seeks to answer the level and extent of involvement of the community to the government services planning to explore how radical information technologies may work to improve the government services to the citizen as an input to e-Governance initiative.

\section{LITERATURE REVIEW}

There are a range of methods and associated studies cited in the literature concerned with the evaluation of eparticipation system which focuses on the citizen awareness of e-democracy of a country. Also, some of the literature and studies support citizen involvement to gain good relationship in building a strong community. Using eparticipation in the government, the researchers found 3 works that mention the use of e-participation.

First, Tambouris et al. (2007) discussed the different platforms of e-participation that can be integrated in the portal: e-consulting, e-informing, e-involving, e-collaborating, and e-empowerment. It is well observed that the role of citizens vary throughout the e-participation stages from citizens to officials. Information and Communication Technology (ICT) tools help the community to express, communicate and collaborate in different aspects in the government policy and decision making. The development and implementation of different edemocracy projects have significantly increased municipal openness and transparency (Petrauskas, 2012). Internal municipality changes allow the improvement of new technology at the same time, inform and teach both the municipal staff and the society on how to use it properly. Moreover, Guzman, Zaplan, Austria and Siy (2014) conducted a study and used Ann Macintosh's E-Participation Model which was integrated in the website to identify problems in the areas of information dissemination, information aggregation, transparency, accountability and scope. The study helped the researchers to identify factors affecting E-Participation involvement in the barangay level as the primary implementing units of the Government.

The researchers adopted Tambouris' e-participation model as the theoretical basis of the study. The following are types of e-participation model: e-informing, e-consulting, c-involving, e-collaboration, and e-empowerment. These were used to work out and identify problem areas. E-informing provides all the latest announcements and events of the barangay through the web portal. Through e-consulting, citizens will provide feedback on all the imposed policies, projects conducted by the barangay for proper evaluation and monitoring. By instituting einvolvement, concerns within the barangay can be raised by the citizens themselves. These reports will be seen by proper authorities for immediate action. Next, is on e-collaboration, by means of the web portal, citizens can raise suggestions for the betterment of the barangay, monitor implementing policies and projects to assure that these are well managed and taken care off. Moreover, e-empowerment will allow citizens to vote online for project for policy creation and implementation. All concerned are given the freedom to choose what they think is beneficial to them.

With these principles and best practices, the researchers conceptualized the design for the system. Using the eparticipation, collective efforts of the citizens and officials are assured to response to the different community issues and concerns for the development of appropriate strategies for implementing innovative community. Citizens can participate and engage in different government activities, programs and projects which would result to collaboration and government-citizen relationship that would answer demands for transparency at the local level.

\section{METHODOLDGY}

The study explores the concepts, theories, methodologies and technologies in identifying the community involvement level related to the services of the government units. The study focused on integrating e-participation in the Local Government unit specifically in the barangay level which aims to address the concerns of the community and to improve services. The respondents of this study are 251 families with a total population of 1,181 people in the community residing in Barangay 434 Zone 42 Sampaloc, Manila using a cluster, stratified, and fishball sampling.

From the total population, the researcher clustered the residents according to street, and then using stratified sampling, the researcher obtained the population of the street through cluster sampling. Lastly, using fish ball sampling, the researcher picked the respondents based on the computed sample population. Sample population in the different streets was expressed using the Slovin's formula and it identified 154 families as total sample from the 254 family populations. 
To gather comprehensive information, the researchers conducted series of activities such as interview, group focus discussion and survey. Questionnaires were used to collect data to support the rationality of the study. The questionnaires and interviews helped to determine the needs and problems associated with the present situation in the community with respect to community involvement.

Based on the activities conducted, Pre-learning criteria was formulated such that community involvement includes the following: a) respondents' level extent of accessibility to technology, b) ability in computer usage, c) involvement and participation in community programs, d) dissemination of information through web, e) public web applicability, and f) community incident report.

The study used the descriptive statistics from the gathered data to determine the needs of the community. Specifically, mean scores and standard deviation were computed from the results of different statements per category which are found on the survey questions. The standard deviation computed to give an idea on how close the entire set of data is to the average value. The Regression Analysis method was used to identify the factors affecting the involvement of the respondents related to the services of LGU. Regression was also used to model the relationship between the involvement level and pre-learning criteria. Moreover, ANOVA was also applied to identify the difference among the age group, civil status, and educational attainment in their levels of involvement. The $p$-value is compare to the threshold value 0.05 level of significant. The mean was used to compute the central tendency in which the sum of all the values in the data set was divided by the number of values in the data set. These statistical tools were used to get the proper interpretation from the data gathered. Likert's scale was used to address the measurement of the perception of the respondents about the study. The researcher used ranks from 1 to 5 where 5 is the highest and 1 is the lowest rank.

Table 1 shows the Likert's scale to quantify the responses to the questions with the following criteria used. The researchers used various verbal interpretation in the survey questionnaires which shown in Appendix A.

Table 1. Rating, Mean Range and Its Interpretation

\begin{tabular}{|c|c|l|l|l|l|}
\hline Rating & Mean Range & \multicolumn{4}{|c|}{ Verbal Interpretation } \\
\hline 5 & $4.21-5.00$ & Always & Excellent & Highly acceptable & Strong Agree \\
\hline 4 & $3.31-4.20$ & Very often & Good & Acceptable & Agree \\
\hline 3 & $2.61-3.30$ & Sometimes & Sometime & Moderately Acceptable & Neither Agree or Disagree \\
\hline 2 & $1.81-2.60$ & Rarely & Fair & Fairly Acceptable & Disagree \\
\hline 1 & $1.00-1.80$ & Never & Poor & Not Acceptable & Strongly disagree \\
\hline
\end{tabular}

\section{RESULTS AND DISCUSSIDNS}

The data in relation to attempting to answer the research questions came from interviews and survey questionnaires that measured using the Likert's scale. The survey instruments include demographic profile of the respondents and pre-learning criteria assessment in the community involvement listed as follows: a) respondent's level extent of accessibility to technology, b) ability in computer usage, c) involvement and participation in community programs, d) dissemination of information through web, e) public web applicability, and f) community incident report. The researchers identified the demographic profile of the respondents using frequency and percentage from the collected information such as sex, age, educational attainment, and civil status. 
Table 2. Demographic Profile of the Respondents

\begin{tabular}{|l|c|c|}
\hline Demographic Variables & frequency & \% (percentage) \\
\hline Sex & & \\
\hline Male & 76 & 49.4 \\
\hline Female & 78 & 50.6 \\
\hline Age & & \\
\hline $18-25$ & 31 & 20.1 \\
\hline $26-35$ & 31 & 20.1 \\
\hline $36-45$ & 38 & 24.7 \\
\hline $46-55$ & 24 & 15.5 \\
\hline $56-65$ & 18 & 11.7 \\
\hline $65-$ above & 12 & 7.8 \\
\hline Status & & \\
\hline Single & 70 & 45.5 \\
\hline Married & 84 & 54.5 \\
\hline Educational Attainment & & \\
\hline High School Undergraduate & 38 & 24.7 \\
\hline High School Graduate & 44 & 28.6 \\
\hline College Undergraduate & 28 & 18.2 \\
\hline College Graduate & 44 & 28.6 \\
\hline
\end{tabular}

Table 2 shows the demographic profile of the respondents according to sex, age, status, and education attainment. In terms of sex, there are 76 males and 78 females with $49.4 \%$ and $50.6 \%$, respectively. The plurality of the respondents belongs to the age group 36-45y/o with a percentage of 24.7. The ages $18-25$ years old and 26-35 years old are tied with a frequency of 31 that has a percentage of 20.1. The next age group with the most respondents is of the age 46-55 years old with a frequency and percentage of 24 and $15.6 \%$, respectively. The age group 56-65 has a frequency of 18 with a percentage of $11.7 \%$. Finally, the age group with the least respondents is the above 65 year-old range with a frequency of 12 which represents only $7.8 \%$ of the total respondents.

Majority of the respondents are married with a percentage of $54.5 \%$ and a frequency of 84 . The remaining $45.5 \%$ of the respondents are single. The obtained result is that $28.6 \%$ of the respondents are high-school and college graduates each having a frequency of 44 . Thirty-eight $(24.7 \%)$ have high-school level education. There are only $28(18.2 \%)$ college-level participants in the study.

Table 3 depicts the results of the pre-learning criteria assessment questionnaires taken from the respondents of the study. The results were obtained through the use of 5-point Likert's scales. The first two (2) statements in the table describe the participants' levels of knowledge on the use of technology. The respondents evaluated the Accessibility to Technology as "often". This obtained a computed mean of 4.30 with a standard deviation of 0.13 . This shows that respondents are able to utilize the different devices to access different kinds of information. Having access to technology is a necessary first step (Araque et al., 2013 cited in Wihbey, 2013). According to Lenhart et al. (2015), accessibility to technology provided by mobile devices, especially smartphones, gave users convenience and increased access to go online-based information. Despite that, Morrison and Barnett (2010) indicated that what is more important is not accessibility of technology but questions how technology can improve social interaction in the community.

The third and the fourth statements explore the community's level of involvement and Participation in Community Programs which obtained a result of (insert numerical value) interpreted as "rarely". This was shown by the computed mean of 2.33 with a standard deviation of 0.18 . This shows that respondents are not totally aware and participative in the different activities given by barangay officials in the community. Accordingly, lack of involvement and awareness of citizen is the most critical problem (Madhukumar \& Ramesh, 2012). This is the same problem encountered in the study Guo, Geng, Sterr, Zhu, and Liu (2017) that residents are still reluctant to take responsibility and lack the knowledge about community activities.

Moreover, the respondents evaluated the level of public web applicability obtained a result and verbal interpretation of "agree". This was shown by a computed mean of 4.20 with a standard deviation of 0.20 . This 
shows that respondents wanted to have a tool essential for dissemination of information and interaction with the barangay officials. According to Zhang, Wang and Duan (2016), Information and Communication Technologies (ICTs) has evolved from the traditional to modern practice of disseminating information to people. Moreover, in the digital environment, it has become possible to enable the users to access community information from anywhere at any time (Chatterjee, 2016). Lastly, when new technologies are applied to community design and planning processes, technologies can empower residents to actively engage in decision-making, foster connections across social groups, with positive consequences on life and socialization in public spaces (Ruggeri \& Young, 2016).

Lastly the (6th) statement described the assessment on incident report in the community as having gained a 3.99 mean which is described as "rarely". This shows that respondents are not well-informed of the different problems, incident and issues occurred in the barangay where in fact, computer and web-based applications provide plenty of opportunities to extend concept of group learning and information dissemination (Wang, Cheng, Chen, Mercer, \& Kirschner, 2017). Analyses found that communities are ready to utilize technology. However, the technical support needs to have an enhanced internet access and better computer facilities. Also, trainings are recommended for utilizing the technology (Azlim, Amran, \& Rusli, 2015).

Table 3. Pre-Learning Assessment Criteria

\begin{tabular}{|l|c|c|c|}
\hline \multicolumn{1}{|c|}{ Pre-Learning Criteria } & $\begin{array}{c}\text { Response } \\
\text { Mean }\end{array}$ & $\begin{array}{c}\text { Standard } \\
\text { Deviation }\end{array}$ & Interpretation \\
\hline 1. Respondents' level of accessibility to technology & 4.3 & 0.13 & Very Often \\
\hline 2. Respondents' level of ability in computer usage & 3.8 & 0.15 & Good \\
\hline $\begin{array}{l}\text { 3. Respondents' level of dissemination of information } \\
\text { through the web }\end{array}$ & 1.41 & 0.2 & Never \\
\hline 4. Respondents' level of public web applicability & 4.2 & 0.2 & Agree \\
\hline $\begin{array}{l}\text { 5. Respondents' level of assessment on incident report in the } \\
\text { community }\end{array}$ & 1.92 & 0.27 & Rarely \\
\hline
\end{tabular}

Table 4 shows the involvement level of the respondents which obtained a mean of 2.33 with a standard deviation of 0.18 and interpretation of "rarely".

Table 4. Community Involvement Level of the Respondents

\begin{tabular}{|c|c|c|c|}
\hline Statements & $\begin{array}{c}\text { Response } \\
\text { Mean }\end{array}$ & $\begin{array}{c}\text { Standard } \\
\text { Deviation }\end{array}$ & Interpretation \\
\hline Respondents' level of involvement in the community? & 2.33 & 0.18 & Rarely \\
\hline
\end{tabular}

Table 5 shows the $F$-value, $p$-value and verbal interpretation of the demographic profile and their community involvement. The demographic profile of the respondents proved not significant except on the category age of the respondents. Results showed that the age group community involvement varies significantly by age group and that there is a positive association between community population aging and community involvement.

Table 5. ANOVA Computation on the differences between the demographic profile of the respondents and their community involvement

\begin{tabular}{|l|c|c|c|c|}
\hline \multicolumn{1}{|c|}{ Demographic Profile } & $\boldsymbol{F}$-value & $\boldsymbol{p}$-value & df & Verbal interpretation \\
\hline Sex & 0.334 & 0.564 & 1 & Not Significant \\
\hline Age & 26.319 & 0.003 & 5 & Significant \\
\hline Civil Status & 0.676 & 0.412 & 1 & Not Significant \\
\hline Educational Attainment & 1.300 & 0.277 & 3 & Not Significant \\
\hline
\end{tabular}

Table 6 shows the regression analysis of levels of involvement in terms of pre-learning criteria of the respondents. Accessibility to technology of the respondents, dissemination of information through web of the respondents, level of public web applicability of the respondents, and level of assessment on incident report in the community of the respondents affected the participants' level of involvement. 
Among the pre-learning criteria, only the ability in computer usage of the respondents proved not a factor in the involvement of the respondents because the $p$-value is greater than the 0.05 level of significance. The linear model is acceptable because the constant is not significant. Moreover, it has an Adjusted R-square of 0.234 and $F$-value of 8.774 which means the accuracy is only $23.4 \%$.

Table 6. Regression Analysis of the Involvement and Pre-learning criteria

\begin{tabular}{|c|c|c|c|}
\hline Pre-learning criteria & Beta Coefficient & $t$-value & $p$-value \\
\hline Constant & & 0.632 & 0.528 \\
\hline $\begin{array}{l}\text { Accessibility to Technology of the } \\
\text { Respondents }\end{array}$ & 0.263 & 3.679 & 0.000 \\
\hline $\begin{array}{l}\text { Dissemination of Information through } \\
\text { Web of the respondents }\end{array}$ & 0.222 & 3.099 & 0.002 \\
\hline $\begin{array}{l}\text { Level of Ability in Computer Usage of } \\
\text { the Respondents }\end{array}$ & 0.55 & 0.770 & 0.443 \\
\hline $\begin{array}{l}\text { Level of Public Web Applicability of } \\
\text { the Respondents }\end{array}$ & 0.171 & 2.411 & 0.017 \\
\hline $\begin{array}{l}\text { Level of Assessment on Incident } \\
\text { Report in the Community of the } \\
\text { Respondents }\end{array}$ & 0.195 & 2.691 & 0.008 \\
\hline
\end{tabular}

\section{CONCLUSIDNS AND RECDMMENDATIONS}

This paper provides an analysis of community involvement in Barangay 434, Sampaloc, Manila. The statistical analysis supported by relevant literature reviews identified community issues related to community involvement in the services of the LGU. The findings provided justifications to identify factors affecting the involvement of the respondents towards the services of the LGU. It also indicated that participants have the same level of involvement in terms of sex, civil status, and educational attainment. However, there is a positive association between community involvement and community respondent age group in terms of involvement level.

Moreover, findings of the study showed that there is a lack of information dissemination about the different services, programs, activities and projects in the community that cause low community involvement. Accessibility to technology of the respondents, dissemination of information to the respondents through web, level of public web applicability of the respondents, and level of assessment on incidents report in the community of the respondents were found to be the factors affecting the involvement of the respondents in the different services of local government officials which leads as a basis for creating the E-participation website for local government unit. It is unapologetic in advocating the use of a technology that has the potential to transform community-LGU relationship. The participants expressed that they want this form of involvement and participation and for their feedback and engagement to be used to improve both the services offered and motivate citizen to take an interest in political and civic issues.

For future studies, managing a research will serve better comprehension of the different variables influencing the significance of dynamic cooperation. The use of ICT in the local government must be applied in a bigger community or group in a barangay, on the other hand local municipalities must implement the proposed system or E-participation portal to identify the benefits derived from the delivery of the services from LGU officials.

\section{IMPLICATIONS}

The findings of this study provide direct implications for community involvement level of the respondents through government services which serves as a foundation for e-participation; however, there is a lack of information dissemination because of the absence of the government information system that would address community issues. The researchers suggest that, the implementation of a series of seminars and ICT training in the community is important in order to automate public sector functions and introduce e-participation which will promote the effective utilization of technology. The development of government services such as e-participation 
initiatives inevitably need to be taken into consideration to provide proper information dissemination, crafting of new models of policy formulation; and alternative approaches for connecting people to the political process though ICT.

Motivations for community involvement are also important. Future efforts could help the community become aware that their involvement will make a difference in changing the local conditions they are not pleased with. Uses of this finding in program/policy development could take a variety of forms. If the community is provided with related government information system, it would be more likely to be active participants in community development efforts. Such ability sends the message that they are welcome in the decision-making process, that their opinions are valuable, that they are capable of good decision making, and that they have the knowledge and understanding of issues that would significantly contribute to the betterment of the community

\section{REFERENCES}

Araque, J. C., Maiden, R. P., Bravo, N., Estrada, I., Evans, R., Hubchik, K., ..., \& Reddy, M. (2013). Computer usage and access in low-income urban communities. Computers in Human Behavior, 29(4), 1393-1401.

Azlim, M., Amran, M., \& Rusli, M. R. (2015). Utilization of educational technology to enhance teaching practices: Case study of Community College in Malaysia. Procedia-Social and Behavioral Sciences, 195, 1793-1797.

Balahadia, F. F., Fabito, B. S., \& Fernando, M. C. G. (2015). E-Participation: Incident mapping portal for local government units. In Humanoid, Nanotechnology, Information Technology, Communication and Control, Environment and Management (HNICEM), 2015 International Conference on (pp. 1-6). IEEE.

Chatterjee, A. (2016). Elements of information organization and dissemination. MA, USA: Chandos Publishing Elsevier.

Guo, B., Geng, Y., Sterr, T., Zhu, Q., \& Liu, Y. (2017). Investigating public awareness on circular economy in western China: A case of Urumqi Midong. Journal of Cleaner Production, 142, 2177-2186.

Guzman, J., Zaplan, R., Austria, D., \& Siy, J. (2014). E-participation: Bridging the gap for better governance. Presented Paper at DLSU Research Congress 2014.

Haase, T., \& Pratschke, J. (2003). Digital divide: Analysis of the uptake of information technology in the Dublin region. Dublin: Printwell Co-operative.

Lenhart, A. (2003). The ever-shifting internet population: A new look at access and the digital divide. Pew Research Center. Retrieved from http://www.pewinternet.org/2003/04/16/the-ever-shifting-internet-populationa-new-look-at-internet-access-and-the-digital-dividel

Lenhart, A., Duggan, M., Perrin, A., Stepler, R., Rainie, H., \& Parker, K. (2015). Teens, social media \& technology overview 2015, Pew Research Center. Retrieved from http://www.pewinternet.org/files/2015/04/PI_TeensandTech_Update2015_0409151.pdf

Madhukumar, S., \& Ramesh, G. (2012). Study about awareness and practices about health care waste management among hospital staff in a medical college hospital, Bangalore. Iranian Journal of Basic Medical Sciences, 3(1), 7-11.

McCaffrey, C. (2003). The Digital divide in the EU: National policies and access to ICTs in the member states. Dublin: Oscail - National Distance Education Centre, DCU.

Morrison, J., \& Barnett, A. (2010). Older people, technology and community. Retrieved from: http://www.cisco.com/c/dam/en_us/about/ac79/docs/wp/ps/Report.pdf

Petrauskas, R. (2012). E-democracy projects in the regions of Lithuania: Evaluation aspects. Social Technologies, 2(2), 404-419.

Ruggeri, D., \& Young, D. (2016). Community in the information age: Exploring the social potential of web-based technologies in landscape architecture and community design. Frontiers of Architectural Research, 5(1), 1526.

Sciadas, G. (2002). Monitoring the digital divide: An ORBICOM-CIDA project report. Quebec, Canada: National Research Council Canada (NRC).

Tambouris, E., Macintosh A., Aichhholzer, G., Winker, R., Coleman, S., \& Wimmer, M. (2007). Introducing eparticipation. DEMO-net booklet Series 1, Canada: DEMO-net The Democracy Network.

Wang, M., Cheng, B., Chen, J., Mercer, N., \& Kirschner, P. A. (2017). The use of web-based collaborative concept mapping to support group learning and interaction in an online environment. The Internet and Higher Education, 34, $28-40$.

Wihbey, J. (2013). Computer usage and access in low-income urban communities. Retrieved from https://journalistsresource.org/studies/society/internet/computer-usage-access-low-income-urban-communities

Zhang, Y., Wang, L., \& Duan, Y. (2016). Agricultural information dissemination using ICTs: A review and analysis of information dissemination models in China. Information Processing in Agriculture, 3(1), 17-29. 


\section{Appendix A. Survey Questions}

Directions: Kindly provide honest answers to the questions. Please read each question carefully and check the box provided that best describes your notion about the question.

\section{RESPONDENT'S PROFILE}

1. Name (Optional):

2. Gender:
$\square \quad$ Female

$\square \quad$ Male

3. Age:

$\square \quad 18-25$

$\square \quad 26-35$

$\square \quad 36-45$

4. Civil Status

$\square \quad$ Single

$\square \quad$ Married

$\square \quad$ Separated

$\square \quad$ Widowed

5. Educational Attainment:

$\square \quad$ Elementary Graduate

$\square \quad$ Elementary Undergraduate

$\square \quad$ High School Graduate

$\square \quad$ High School Undergraduate

$\square \quad$ College Graduate

$46-55$

$56-65$

Over 65

Directions: Choose scales from 1 to 5 by putting a check in the box provided for your answer on your perception about the study.

\section{ACCESIBILTY TO TECHNOLOGY}

$$
5 \text { - ALWAYS } \quad 4 \text { - VERY OFTEN } \quad 3 \text {-SOMETIMES } \quad 2 \text {-RARELY } 1 \text {-NEVER }
$$

\begin{tabular}{|c|c|c|c|c|c|}
\hline & 1 & 2 & 3 & 4 & 5 \\
\hline 1. I use desktop, laptop, smartphones, or tablets. & & & & & \\
\hline 2. I have an internet access either at home or in the office. & & & & & \\
\hline $\begin{array}{l}\text { 3. I have a social media account, e.g., Facebook, Twitter, Instag } \\
\text { e-mail, etc. }\end{array}$ & & & & & \\
\hline 4. I frequently use my social media account. & & & & & \\
\hline $\begin{array}{l}\text { 5. I use these portals in learning about current events and other } \\
\text { issues in the community. }\end{array}$ & & & & & \\
\hline
\end{tabular}

\section{LEVEL OF ABILITY IN COMPUTER USAGE}
5 - EXCELLENT
$4-$ GOOD
3 - AVERAGE
2 - FAIR
$1-$ POOR

\begin{tabular}{|c|c|c|c|c|c|}
\hline & 1 & 2 & 3 & 4 & 5 \\
\hline $\begin{array}{l}\text { 1. Knowledge in operating the computer and/or gadget such as } \\
\text { turning on and shutting down the unit, connecting to the internet, } \\
\text { composing texts and other files, and saving and retrieving data }\end{array}$ & & & & & \\
\hline $\begin{array}{l}\text { 2. Knowledge in the operating systems of the computer or gadgets } \\
\text { used }\end{array}$ & & & & & \\
\hline $\begin{array}{l}\text { 3. Knowledge and skills in office productivity, e.g., MS Word, MS } \\
\text { Excel, MS PowerPoint }\end{array}$ & & & & & \\
\hline $\begin{array}{l}\text { 4. Knowledge in the use of internet as a source in research and } \\
\text { means of communication and information dissemination }\end{array}$ & & & & & \\
\hline $\begin{array}{l}\text { 5. Knowledge in the use of web browsers, instant messages, e- } \\
\text { mails, and other web based applications }\end{array}$ & & & & & \\
\hline
\end{tabular}




\section{LEVEL OF AWARENESS AND PARTICIPATION IN COMMUNITY PROGRAMS}
5 - ALWAYS
4 - VERY OFTEN
3 - SOMETIMES
2 - RARELY
1 - NEVER

\begin{tabular}{|c|c|c|c|c|c|}
\hline & 1 & 2 & 3 & 4 & 5 \\
\hline 1. Meetings conducted by the barangay council to the community & & & & & \\
\hline $\begin{array}{l}\text { 2. Different programs and activities counted by the barangay } \\
\text { council }\end{array}$ & & & & & \\
\hline $\begin{array}{l}\text { 3. Information dissemination through: } \\
3.1 \text { Bulletin board } \\
3.2 \text { Posters } \\
3.3 \text { House to House } \\
3.4 \text { Social Media } \\
\end{array}$ & & & & & \\
\hline $\begin{array}{l}\text { 4. I attend to the services offered by the barangay: } \\
4.1 \text { Public Hearing } \\
4.2 \text { Barangay Programs } \\
4.3 \text { Program design and planning and decision making }\end{array}$ & & & & & \\
\hline $\begin{array}{l}\text { 5. I assert my knowledge and ideas with regards to: } \\
5.1 \text { Current issues in the barangay } \\
5.2 \text { Feedback and recommendation as an evaluation of barangay } \\
\text { programs and activities }\end{array}$ & & & & & \\
\hline
\end{tabular}

\section{DISSEMINATION OF INFORMATION THROUGH WEB}
5 - ALWAYS
4 - VERY OFTEN
3 - SOMETIMES
2 - RARELY
1 - NEVER

\begin{tabular}{|c|c|c|c|c|c|}
\hline \multirow{2}{*}{$\begin{array}{l}\text { 6. The barangay council disseminates information through social } \\
\text { media, e.g., Facebook, Twitter, Instagram, etc. }\end{array}$} & 1 & 2 & 3 & 4 & 5 \\
\hline & & & & & \\
\hline 7. The barangay has its own website or any social media account. & & & & & \\
\hline $\begin{array}{l}\text { 8. The community has a means of communication with the } \\
\text { barangay through web, vice-versa, the barangay is using this } \\
\text { portal to adhere in the transparency of their service. }\end{array}$ & & & & & \\
\hline $\begin{array}{l}\text { 9. The barangay council provides a web wherein the community } \\
\text { could express their opinions, suggestions, and recommendations. }\end{array}$ & & & & & \\
\hline $\begin{array}{l}\text { 10. The barangay council provides an avenue to assert concerns and } \\
\text { problems in the community through web. }\end{array}$ & & & & & \\
\hline
\end{tabular}

\section{LEVEL OF PUBLIC WEB APPLICABILITY}

\section{5 - STRONGLY AGREE $\quad 4$ - AGREE 3 - NEITHER AGREE NOR DISAGREE 2 - DISAGREE 1 -STRONGLY DISAGREE}

11. The web could be a tool in the expression of ideas, opinions, suggestions, and recommendations with regard to programs and activities.

12. The web is an avenue for the members of the barangay to participate in brainstorming during designing and planning, and decision-making of not only with its programs and activities but also with policy-making and implementation.

13. Nowadays, a web is essential for any organization because of its accessibility. This could also be a tool for transparencies of service because the officials may post biddings and expenditures of the barangay.

14. The web is an essential tool in dissemination of information and other important matters that community members must know.

15. The web will improve the means of communication between the barangay officials and community members. This will improve the governance of the public officials. 


\section{LEVEL OF ASSESSMENT ON INCIDENTS REPORT IN THE COMMUNITY}

\section{5 - ALWAYS \\ 4 - VERY OFTEN \\ 3 - SOMETIMES \\ 2 - RARELY \\ 1 - NEVER}

\begin{tabular}{|c|c|c|c|c|c|}
\hline & 1 & 2 & 3 & 4 & 5 \\
\hline $\begin{array}{l}\text { 1. I am aware of the different incident or problems occurring in the } \\
\text { community. }\end{array}$ & & & & & \\
\hline $\begin{array}{l}\text { 2. I am able to freely report any incident occurring in our } \\
\text { community to the barangay }\end{array}$ & & & & & \\
\hline $\begin{array}{l}\text { 3. I am able to collaborate with other citizens with regards to the } \\
\text { incidents identified to the barangay }\end{array}$ & & & & & \\
\hline $\begin{array}{l}\text { 4. The barangay council quickly responses to the incidents reported } \\
\text { to them. }\end{array}$ & & & & & \\
\hline $\begin{array}{l}\text { 5. I am informed of the development of the incidents reported to the } \\
\text { barangay. }\end{array}$ & & & & & \\
\hline
\end{tabular}

